\title{
Variation of medium osmolalities induces changes in cilia related signalling pathways in primary cultured renal inner medullary collecting duct cells
}

\author{
B Edemir ${ }^{*}$ M Jardzejewski, E Schlatter \\ From First International Cilia in Development and Disease Scientific Conference (2012) \\ London, UK. 16-18 May 2012
}

Compared to other organs the cells of the renal inner medulla are challenged with an environment of highly variable osmolality. Cellular adaption to changing osmolality is associated with changes in gene expression. To identify novel genes and pathways that are affected by high osmolality we performed microarray experiments using primary cultured rat inner medullary collecting duct cells cultivated at 300,600 , or $900 \mathrm{mosmol} / \mathrm{kg}$ for six days. Compared to $300 \mathrm{mosmol} / \mathrm{kg}$ more than 2000 genes showed significant changes in expression at 600 or 900 mosmol/kg. Pathway analysis revealed that the WNT/betacatenin pathway was also affected. Western blot analysis confirmed the down regulation of beta-catenin and of phosphorylated beta-catenin protein. Immunofluorescence analysis indicated massive changes in intracellular localization of beta-catenin. At $300 \mathrm{mosmol} / \mathrm{kg}$ beta-catenin was distributed diffusively within the cells. At higher osmolalities beta-catenin was concentrated at the cell to cell contacts and in the nucleus. Similar effects were observed for phosphorylated beta-catenin. We also observed striking changes in cell morphology. While at $300 \mathrm{mosmol} / \mathrm{kg}$ the actin filaments were diffusively distributed the cultivation at $600 \mathrm{mosmol} / \mathrm{kg}$ was associated with massive reorganisation and enrichment of the actin filaments at the cell to cell contacts. Staining of the microtubules with betatubulin clearly showed the primary cilia in cells cultivated at $300 \mathrm{mosmol} / \mathrm{kg}$. Surprisingly the length of the cilia was drastically reduced in cells cultivated at $600 \mathrm{mosmol} / \mathrm{kg}$. The analysis of the underlying physiological mechanisms and the consequences for cilia related signalling at

\footnotetext{
* Correspondence: edemir@uni-muenster.de
} University Hospital Münster, Germany

C 2012 Edemir et al; licensee BioMed Central Ltd. This is an Open Access article distributed under the terms of the Creative Commons Attribution License (http://creativecommons.org/licenses/by/2.0), which permits unrestricted use, distribution, and reproduction in any medium, provided the original work is properly cited. different osmolalities could help to add new aspects to cilia function.

Published: 16 November 2012

doi:10.1186/2046-2530-1-S1-P21

Cite this article as: Edemir et al:: Variation of medium osmolalities induces changes in cilia related signalling pathways in primary cultured renal inner medullary collecting duct cells. Cilia 2012 1(Suppl 1):P21.

Submit your next manuscript to BioMed Central and take full advantage of:

- Convenient online submission

- No space constraints or color figure charges

- Immediate publication on acceptance

- Inclusion in PubMed, CAS, Scopus and Google Scholar

- Research which is freely available for redistribution
- Thorough peer review 